\title{
Penerapan Keselamatan dan Kesehatan Kerja Pada Perawat di Instalasi Gawat Darurat (IGD)
}

\author{
Riana Silvia Casuarina L.Tobing \\ riana.sct@gmail.com
}

\section{Latar Belakang :}

Perawat merupakan petugas kesehatan dengan presentasi terbesar dan memegang peranan penting dalam pemberian pelayanan kesehatan. Dalam menjalankan tugasnya perawat berisiko mengalami gangguan kesehatan dan keselamatan kerja (K3). Penelitian ini bertujuan untuk menganalisis risiko K3 pada perawat di instalasi gawat darurat (IGD). Pelaksanaan Keselamatan dan Kesehatan Kerja (K3) adalah salah satu bentuk upaya untuk menciptakan tempat kerja yang aman, sehat, dan bebas dari pencemaran lingkungan, sehingga dapat mengurangi dan atau bebas dari kecelakaan kerja dan penyakit akibat kerja yang pada akhirnya dapat meningkatkan efisiensi dan produktivitas kerja. Kecelakaan kerja tidak saja menimbulkan korban jiwa maupun kerugian materi bagi pekerja dan pengusaha, tetapi juga dapat mengganggu proses produksi secara menyeluruh, merusak lingkungan yang pada akhirnya akan berdampak pada masyarakat luas. Menurut Undang-undang No. 44 Tahun 2009 Rumah Sakit adalah institusi pelayanan kesehatan bagi masyarakat dengan karakteristik tersendiri yang dipengaruhi oleh perkembangan ilmu pengetahuan kesehatan, kemajuan teknologi, dan kehidupan sosial ekonomi masyarakat yang harus tetap mampu meningkatkan pelayanan yang lebih bermutu dan terjangkau oleh masyarakat agar terwujud derajat kesehatan yang setinggi-tingginya. Dari pengertian tersebut, rumah sakit melakukan beberapa jenis pelayanan diantaranya pelayanan medik, pelayanan penunjang medik, pelayanan perawatan, pelayanan rehabilitasi, pencegahan dan peningkatan kesehatan, sebagai tempat pendidikan, pelatihan medik dan para medik, sebagai tempat penelitian, pengembangan ilmu dan teknologi bidang kesehatan. Selain dituntut mempu memberikan pelayanan dan pengobatan yang bermutu, Rumah Sakit juga dituntut harus melaksanakan dan mengembangkan program Kesehatan dan Keselamatan Kerja di Rumah Sakit (K3RS) seperti yang tercantum dalam buku Standar Pelayanan Rumah Sakit dan terdapat dalam 
instrumen akreditasi Rumah Sakit. Dalam Undang-Undang Nomor 36 Tahun 2009 tentang Kesehatan, Pasal 165 : pengelola tempat kerja wajib melakukan segala bentuk upaya kesehatan melalui upaya pencegahan, peningkatan, pengobatan, dan pemulihan bagi tenaga kerja. Berdasarkan pasal tersebut maka pengelola tempat kerja di Rumah Sakit mempunyai kewajiban untuk menyehatkan para tenaga kerjanya. Salah satunya adalah melalui upaya kesehatan kerja disamping keselamatan kerja. Rumah Sakit harus menjamin kesehatan dan keselamatan baik terhadap pasien, penyedia layanan atau pekerja maupun masyarakat sekitar dari berbagai potensi bahaya di Rumah Sakit. Oleh karena itu, Rumah Sakit dituntut untuk melaksanakan Upaya Kesehatan dan Keselamatan Kerja (K3) yang dilaksanakan secara terintegrasi dan menyeluruh sehingga risiko terjadinya Penyakit Akibat Kerja (PAK) dan Kecelakaan Akibat Kerja (KAK) di Rumah Sakit dapat dihindari. Penyakit akibat kerja di rumah sakit dapat menyerang semua tenaga kerja baik medis maupun non medis Sehingga sasaran utama K3RS adalah tenaga medis, tenaga non medis, pasien, pengunjung / pengantar pasien, serta masyarakat sekitar Rumah Sakit. Perawat merupakan petugas kesehatan dengan presentasi terbesar dan memegang peranan penting dalam pemberian pelayanan kesehatan. Dalam menjalankan tugasnya perawat berisiko mengalami gangguan kesehatan dan keselamatan kerja (K3). Penelitian ini bertujuan untuk menganalisis risiko $\mathrm{K} 3$ pada perawat di instalasi gawat darurat (IGD) dan kemampuan baik jasminah maupun rohani tenaga kerja pada khususnya dan manusia pada umumnya serta hasil karya dan budayanya. Dari segi keilmuaan diartikan sebagai suatu pengetahuan dan penerepannya dalam usaha mencegah kemungkinan terjadinya kecelakaan dan penyakit akibat kerja.

\section{Tujuan :}

Untuk mengetahui Penerapan Keselamatan dan Kesehatan Kerja pada Perawat di Instalasi Gawat Darurat( IGD) mengetahui faktor-faktor bahaya yang dihadapi oleh perawat, mengetahui urutan prioritas dari bahaya yang sudah terindentifikasi dan faktor-faktor yang berhubungan dengan Penerapan Keselamatan dan Kesehatan Kerja Pada Perawat. 


\section{Metode:}

Jurnal ini menggunakan metode tersearch dan analisis dari berbagai sumber seperti buku teks, buku referensi jurnal, e-book, dan Thesis dengan menggunakan Google Scholar, Jurnal Keperawatan Indonesia. yang berhubungan Penerapan Keselamatan dan Kesehatan Kerja pada Perawat di Instalasi Gawat Darurat( IGD). Dari berbagai sumber informasi digunakan untuk mengetahui pengaruh faktorfaktor yang berhubungan dengan Penerapan Keselamatan dan Kesehatan Kerja pada Perawat di IGD. Pengolahan jurnal dilakukan dengan metode Data diambil dengan menggunakan instrumen pernyataan faktor-faktor bahaya yang dapat mempengaruhi Pengambilan keputusan Klinis Perawat dengan tersearch dan analisis dari berabgai sumber seperti membandingkan beberapa jurnal yang berhubungan Penerapan Keselamatan dan Kesehatan Kerja pada Perawat di Instalasi Gawat Darurat( IGD).

\section{Hasil :}

World Heatlh Organitations (WHO) tercatat dari 35 juta pegawai kesehatan di dunia, kematian akibat penyakit menular yang berhungan dengan pegawaian kesehatan berjumlah kurang lebih 108.254 laki-laki dan perempuan 517.404 kejadian. Insiden akut secara signifikan lebih besar terjadi pada pegawai rumah sakit dibandingkan dengan seluruh pegawai di semua kategori jenis kepegawaian (3) Pusat Data dan Informasi Kementerian Kesehatan RI tahun 2015, Jumlah kasus kecelakaan kerja di Indonesia sejak tahun 2011 hingga tahun 2014 mengalami fluktuasi, angka tertinggi pada tahun 2013 yaitu 35.917 kasus. Pada tahun 2011 sebanyak 9.891 kasus, tahun 2012 sebanyak 21.735 kasus dan tahun 2014 sebanyak 24.910 kasus. Tiga Provinsi dengan jumlah kecelakaan kerja tertinggi pada tahun 2011 adalah Provinsi Banten, Kalimantan Tengah dan Jawa Timur, tahun 2012 adalah Provinisi Jambi, Maluku dan Sulawesi Tengah, tahun 2013 adalah Provinsi Aceh, Sulawesi Utara dan Jambi sedangkan tahun 2014 adalah Provinsi Sulawesi Selatan, Riau dan Bali (4). Badan Penyelenggara Jaminan Sosial (BPJS) Ketenagakerjaan, tahun 2016. kasus kecelakaan kerja yang terjadi di Provinsi Sulawesi Tengah antara tahun 2014-2015 terjadi kasus kecelakaan sebanyak 524 kasus. Berdasarkan hasil studi pendahuluan yang 
dilakukan pada hari kamis tanggal 14 juli 2016 diketahui bahwa perawat yang bekerja di Ruang Instalasi Gawat Darurat (IGD) Rumah Sakit Umum Anutapura Palu berjumlah 31 perawat, 21 perawat berjenis kelamin laki-laki dan 10 perawat berjenis kelamin perempuan. Kasus Kecelakaan Kerja perawat di Ruang IGD Rumah Sakit Umum Anutapura Palu dalam kurung waktu 3 bulan (Januari-Maret 2016 tercatat 19 kasus. Dari hasil permasalahan ini perlu mendapatkan perhatian dan penanganan yang baik mengingat pevalensi perawat yang mengalami Kecelakaan Kerja lebih tinggi dibandingkan dengan yang tidak mengalami Kecelakaan. keselamatan dan produktivitas tenaga kerja senantiasa terjamin. Paradigma baru dalam aspek kesehatan mengupayakan agar yang sehat tetap sehat dan bukan sekedar mengobati, merawat dan menyembuhkan gangguan kesehatan atau penyakit. Oleh karenanya, perhatian utama di bidang kesehatan lebih serta pemeliharaan kesehatan seoptimal mungkin. Status kesehatan seseorang, menurut Blum (1981) ditentukan oleh empat faktor yakni :

1) Lingkungan, berupa lingkungan fisik (alami, buatan) kimia (organik/anorganik, logam berat, debu), biologi (virus, bakteri, mikroorganisme) dan sosial budaya (ekonomi, pendidikan, pekerjaan)

2) Perilaku yang meliputi sikap, kebiasaan, tingkah laku.

3) Pelayanan Kesehatan : promotif, preventif, perawatan, perawatan, pengobatan, pencegahan, kecacatan, rehabilitas, dan

4) Genetik, yang merupakan faktor bawaan setiap manusia.Interaksi dari berbagai faktor tersebut sangat mempengaruhi tingkat kesehatan seseorang baik dalam kehidupan sehari-sehari maupun di tempat kerja. Dengan demikian, dalam pengelolaan kesehatan, keempat faktor tersebut perlu diperhatikan, khususnya dalam aspek lingkungan dan pelayanan kesehatan. 
Dalam konsep pengelolaan keselamatan kerja modern (Modern safety Management/ MSM) dikenal dua definisi keselamatan kerja. Pertama, didefinisikansebagai bebas dari kecelakaan-kecelakaan atau bebas dari kondisi sakit, luka atau bebas dari kerugian. Kedua, didefinisikan sebagai pengontrol bebas kerugian. Definisi ini lebih fungsional karena berkaitan dengan luka, sakit, kerusakan harta dan kerugian terhadap proses. Definisi kedua ini juga termasuk dalam hal pencegahan kecelakaan dan mengusahakan seminimum mungkin terjadinya kerugian. Ini ada kaitannya dengan fungsi pengontrolan.Sedang dalam tindak lanjut pengendalian potensi bahaya kesehatan, masing-masing aktivitas dan penanggung jawabnya adalah :

1) Pengenalan terhadap pengaruh kesehatan : pekerja, bagian kesehatan keselamatan kerja, paramedik/dokter.

2) Diagnosis penyakit/gangguan kesehatan : paramedik/dokter.

3) Penetapan faktor penyebab di lingkungan kerja : ahli higiene industri/kerja,paramedik/dokter, ahli toksikologi.

4) Monitoring, pengendalian faktor penyebab : ahli higiene industri, ahli keselamatan kerja, ahli ergonomic, dokter.

5) Monitoring kesehatan : paramedik/dokter, ahli epidemiologi, ahli toksikologi.

\section{Pembahasan :}

Lingkungan Instalasi Gawat Darurat merupakan salah satu tantangan yang sangat berbahaya di Rumah Sakit, terutama karena lingkungannya yang tidak terstruktur dan tergesa-gesa, dengan pasien yang mengalami masalah yang tidak dapat diprediksi, dengan ukuran dan tingkat urgensi pasien yang bervariasi, dan pada waktu yang tidak terjadwal. Pelayanan pasien Gawat Darurat adalah pelayanan yang memerlukan pelayanan segera, yaitu cepat, tepatdan cermat untuk mencegah kematian dan kecacatan, pelayanan ini bersifat penting (emergency) sehingga diwajibkan untuk melayani pasien 24 jam sehari secara terus menerus(Destifiana, 2015).Lingkungan Instalasi Gawat Darurat merupakan salah satu tantangan yang sangat berbahaya di Rumah Sakit, terutama karena lingkungannya yang tidak terstruktur dan tergesa-gesa, dengan pasien yang mengalami masalah yang tidak 
dapat diprediksi, dengan ukuran dan tingkat urgensi pasien yang bervariasi, dan pada waktu yang tidak terjadwal.3 Potensi bahaya menurut peraturan menteri kesehatan no.66 tahun 2016 terdari dari 8 item yaitu potensi bahaya fisik. Kimia, biologi, ergonomi, psikososial, mekanikal dan elektrikal, jenis potensi bahaya ini memliki dampak dan pengaruh yang sangat kuat yang dapat membahayakan komponen rumah sakit. Daftar Occupational Safety and Health Administration (OSHA) Prinsip Bahaya untuk Perawat

1) Patogen melalui darah.

2) Bahan kimia berbahaya : (misalnya, Etilen oksida, obat tumpah, bahan karsigonek, asap berbahaya, dan cairan mudah terbakar).

3) Slips/ jatuh.

4) Alergi lateks : (misalnya, reaksi terhaap sarung tangan terbuat dari lateks alam dan atau bahan yang digunakan untuk membuat sarung tangan. Bahaya peralatan : misalnya kejutan listrik, defribilator.

5) Stess kerja :

a. Faktor-faktor : shift kerja, Jam kerja yang panjang, kelelahan, situasi emotional yang kuat ( penderitaan dan kematian ), keselamatan pasien (kesalahan pengobatan) Resiko yang dihadapi : penyakit jantung, gangguan psikologis, cidera di tempat kerja dan masalah kesehatan lainnya

b. Peringatan dini : sakit kepala, gangguan tidur, kesulitan konsentrasi,

c. ketidakpuasan kerja dan semangat kerja yang turun

7) Infeksi Methicilin Resistant Staphylococcus.

8) Workplace violence : serangan fisik luar (memaki,ancaman).

9) Terorisme : misalnya menerima korban dari sebuah insiden teroris yang tidak diketahui identitasnya.

10) Bahaya fisik : misalnya flying obyects, cidera mata. 
Potensi Bahaya Fisik

Potensi bahaya fisik adalah faktor di dalam tempat kerja yang bersifat fisika, Setiap benda atau proses yang secara langsung atau per-lahan bisa mencederai fisik orang ataupun bagiannya antara lain. Yang merupakan potensi bahaya fisik adalah kebisingan, pencahayaan, getaran, iklim kerja, gelombang mikro dan sinar ultra ungu. Faktor-faktor ini mungkin bagian tertentu yang dihasilkan dari proses produksi atau produk samping yang tidak diinginkan (ILO, 2013).Pencahayaan di IGD dapat dinyatakan aman bagi tenaga kesehatan untuk melakukan tindakan kegawat daruratan dan tindakan medis yang dibutuhkan untuk pasien yang datang ke Instalasi Gawat Darurat, juga aman bagi pasien yang membutuhkan pelayanan gawat darurat dan pelayanan medis lain, maupun untuk keluarga pasien dan pengunjung di Instalasi Gawat Darurat. Hasil observasi untuk mendukung pencahayaan yang baik secara maksimal di Instalasi Gawat Darurat lebih tepatnya pada malam hari menggunakan pencahayaan buatan dan pada siang hari menggunakan pencahayaan alami. erdapat satu potensi bahaya fisik di IGD dari segi lantai, penggunaan lantai telah sesuai dengana pedoman teknis bangunan IGD yaitu menggunakan lantai dengan permukaan ubin yang kasar namun dengan kondisi IGD yang tergesa-gesa dan tidak terstruktur maka dapat terjadi ceceran atau tumpahan cairan yang secara tidak sengaja bersumber dari pasien maupun keluarga pasien, hal inilah yang dapat menjadi sumber potensi bahaya terpeleset di IGD. Dampak yang ditimbulkan akibat terpeleset, tersandung, dan terjatuh tidak pernah sederhana. Tidak hanya mengakibatkan luka ringan, cedera serius/ fatal hingga kematian bagi pekerja, namun juga mengakibatkan kerugian ekonomi bagi perusahaan. Kegitan yang dapat dilakukan untuk mencegah terjadinya insiden terpeleset di Instalasi Gawat Darurat adalah selalu melakukan pembersihan pada lantai setiap saat dan memasang rambu k3 tentang lantai licin ditempat yang terdapat tumpahan atau lantai yang sedangdalam keadaan basa (Safety Sign, 2018).

\section{Potensi Bahaya Biologi}

Potensi bahaya biologi adalah potensi bahaya yang beresiko adalah Pada proses pekerjaan menjahit luka pasien, nilai risiko tertinggi bahaya biologi pada tahap 
pekerjaan merapikan alat (Putri, Arif, \& Subaris , 2017). Potensi bahaya biologi merupakan potensi bahaya yang sangat banyak dijumpai di Rumah Sakit, potensi bahaya biologi termasuk dalam kelompok virus, bakteri, jamur dan parasite lainnya. Dalam lingkungan rumah sakit sangat banyak dijumpai virus seperti HIV, SARS dan hepatitis yang merupakan bahaya potensial bagi petugas kesehatan dan mereka yang bekerja dilingkungan rumah sakit. Jenis bahaya potensial biologis dapat masuk kedalamtubuh baik melalui kontak langsung dengan cairan tubuh penderita, melalui pernafasan dan melalui system pencernaan (Ekowati, 2009). 13 Hasil penelitian menjunjukan bahwa potensi bahaya Biologi cukup besar dapat memberi Penyakit Akibat Kerja pada petugas kesehatan yang berada di Instalasi Gawat Darurat, hal ini disebabkan karena pasien yang masuk belum diketaui kondisi dan penyakit yang di alaminya namun sebagai petugas medis yang berada di Instalasi Gawat Darurat baik itu perawat maupun dokter harus tetap melakukan langka untuk pertolongan dan pengobatan dalam rangka bertujuan untuk menyelamatkan dan menyembuhkan pasien. Oleh sebab itu diperlukan adanya kesadaran bagi perawat maupun dokter dalam melakukan tindakan harus tetap dalam keadaan aman, menggunakan APD wajib walaupun belum diketahui penyakitnya.14 Potensi bahaya berkaitan dengan infeksi atau agen biologis seperti bakteri, virus dan jamur yang dapat ditularkan melalui kontak langsung dengan pasien terinfeksi atau cairan tubuh. Risiko dari kuman-kuamn patogen dari pasien, risiko ini harus dikendalikan oleh bagian petugas pemantau infeksi Rumah Sakit dan harus dikoordinasikan dengan unit K3RS (Rases, Herryanis, \& Gobel, 2016).15 Peraturan Menteri Kesehatan No 66 tahun 2016 pengendalian risiko bahaya dilakukan dalam rangka pengelolaan dan pengendalian risiko yang berkaitan dengan keselamatan dan Kesehatan Kerja di Rumah Sakit agar terciptanya kondisi Rumah Sakit yang sehat, aman, selamat, dan nyaman bagi sumber daya manusia Rumah Sakit, pasien, pendamping pasien, pengunjung, maupun lingkungan Rumah Sakit.16 Potensi bahaya biologi merupakan potensi bahaya yang sangat banyak dijumpai dirumah sakit, potensi bahaya biologi termasuk dalam kelompok virus, bakteri, jamur dan parasit lainnya. Salah satu tempat di Rumah Sakit yang mempunyai potensi bahaya biologis yang besar adalah Instalasi Gawat Darurat, hal ini disebabkan karena jenis pasien yang masuk 
di Instalasi Gawat Darurat belum diketahui pasien tersebut memiliki penyakit apa. Instalasi Gawat Darurat Rumah Sakit telah menerapkan sistem START atau ruang triase yang fungsinya untuk melakukan pemilahan pasien masuk dalam jalur merah, kuning, atau hijau. Pasien yang masuk akan dianalisis tanda dan gejala penyakitnya terlebih dahulu, misalnya ada tanda batuk yang lebih dari 1 minggu atau memiliki tanda dan gejala infeksi maka pasien tersebut dimasukkan kedalam khusus yaitu ruangan isolasi, ruangan ini ditempakan pasien yang memiliki riwayat penyakit menular yang bisa membahayakan pasien lain maupun petugas kesehatan.17 Berdasalkan hasil analisis risiko AS/NZS 4360:1999 potensi bahaya biologi di IGD RSUD Kota Kendari dijelaskan sebagai berikut:

a) Terkena penyakit menular karena sering terpapar pada saat Pemeriksaan awal/validasi pasien diruang Triase, Menjelaskan hasil anamnesa kepada pasien dan keluarga dan pada saat perawat dan dokter menjelaskan alur pelayanan di rumah sakit merupkan salah satu penyebab penularan penyaki yang dapat dialami oleh tenaga kesehatan yang disebabkan oleh penyakit yang ditularkan oleh pasien (Maramis, Umboh, \& Pinontoan, 2018).

b) Tertusuk aboket saat tindakan pemasangan infus. Kejadian tertusuk aboket saat hendak memasang infus bukanlah suatu kejadian fatal dan berbahaya, hal ini disebabkan karena jarum aboket tersebut belum digunakan oleh pasien lalu tertusuk keputugas kesehatan. Jika terjadi insiden tersebut jarum yang tidak sengaja tertusuk pada petugas kesehatan tersebut tidak boleh lagi digunakan pada pasien dan harus segera melakukan penggantian aboket baru, hal ini untuk mencegah sesuatu yang tidak diharapkan terjadi pada pasien yang hendak dipasangkan infus. Untuk mencegah terjadinya insiden tertusuk jarum infus maka yang perlu dilakukan adalah selalu menggunakan APD saat hendak melakukan tindakan pemasangaan infus seperti sarung tangan medis.

c) Tertusuk aboket saat melepas infus Insiden tertusuk jarum di Instalasi Gawat Darurat (IGD) jika terjadi maka hal itu merupakan hal yang sangat fatal yang dapat menyebabkan menularnya penyakit dan terjadi infeksi terlebih lagi ketika jarum suntik tersebut telah digunakan untuk injeksi 
pasien yang dipastika positif HIV/AIDS, maka hal yang perlu dilakukan adalah melakukan pemeriksaan medis untuk tes dara agar mengetahui tindakan apan yang selanjutnya dapat dilkukan. Untuk mencegah terjadinya insiden tertusuk jarum maka yang perlu dilakukan adalah selalu menggunakan APD dan lebih berhati-hati dalam melakukan tindakan.

d) Tertusuk jarum saat Tindakan injeksi jika tidak menggunakan APD, jika dinilai memerlukan perhatian dari pihak manajemen dan melakukan tindakan perbaikan cepat dan darurat.

e) Tersayat dan tertusuk saat Menjahit luka saat tidak menggunakan APD. Standar Operasional Prosedur yang tepat dalam penjahitan luka adalah dengan menggunakan pinset anatomis dan chirurgis untuk menahan luka saat melakukan tindakan penjahitan luka hal ini untuk menjegah terjadinya luka tusuk yang terjadi pada petugas kesehatan saat melakukan tindakan penjahitan luka.Pada tindakan menjahit luka terdapat tiga risiko, yaitu tertusuk jarum, luka kena ampul, dan kontak dengan darah pasien yang tertular HIV/AIDS, Hepatitis. Tertusuk jarum jahit terjadi pada tahap penjahitan luka, hal ini terjadi karena perawat menjahit tidak menggunakan pinset untuk menahan tepi luka, tetapi menggunakan jari tangannya sendiri (Ramdan \& Rahman, 2017)

Potensi Bahaya Psikososial

Bahaya psikologis yang terdapat di instalasi gawat darurat seperti tekanan atau intimidasi dari keluarga pasien yang tidak sabar menunggu penanganan dan pemeriksaan dokter atau perawat. Keluarga pasien mengancam petugas medis sampai mengakibatkan beberapa petugas medis mengalami trauma, ada pula yang sampai tidak masuk kerja di hari berikutnya. hubungan antar sesama rekan kerja saat pekerjaan berlangsung terkadang menimbulkan miskomunikasi atau kesalah pahaman dalam berkomunikasi, hal ini secara normal dapat terjadi dalam lingkungan sosial hingga minumbulkan konflik yang kecil hingga konflik besar dan berkepanjangan, namun di Instalasi Gawat Darurat dalam hubungan antar sesama pekerja miskomunikasi biasa dapat terjadi namun hal itu dapat diatasi dengan baik dengan melakukan komunikasi agar tidak terjadi kesalah pahaman 
yang berkepanjangan dan akhirnya berdampak pada pekerjaan.Bahaya psikososial lain yang didapatkan oleh tenaga kesehatan seperti kekerasan secara verbal dalam hal ini memaki, membentak, marah dan teriak serta mengancam tenaga kesehatan merupakan kasus yang kerap terjadi di Instalasi Gawat Darurat. Tindakan kekerasan secara verbal merupakan kekerasan yang seringkali terjadi di Instlasi Gawat Darurat disebabkan oleh kondidi pasien yang masuk dalam keadaan yang gawat dan darurat serta dapat memgancam nyawah pasien tersebut, oleh karena itu kepanikan keluarga pasien bisa menjadi sumber potensi bahaya tersebut dimana keluarga pasien sedang tidak dalam kondisi emosional yang tidak stabil.

Setiap tindakan yang dilakukan oleh perawat mempunyai potensi bahaya berupa bahaya fisik, biologi, dan ergonomi. Bahaya fisik didapatkan pada pekerjaan yang menggunakan alat yang tajam, seperti memasang infus dan menjahit luka. Bahaya biologi terdapat pada tindakan invasif, merawat luka, memasang infuse, dan memberikan obat melalui rektal. Sedangkan postur janggal ketika membungkuk merupakan bahaya pekerjaan karena faktor ergonomi. Hasil penelitian ini sesuai dengan penelitian di negara berkembang lainnya oleh Ndejjo et al. (2015) yang menyimpulkan tenaga kesehatan di rumah sakit di Uganda terpapar bahaya (hazard) biologis dan nonbiologis. Paparan hazard biologis terdiri dari tertusuk jarum, luka gores, terpapar spesimen atau materi biologis lainnya, terkena penyakit yang ditularkan lewat udara, penyakit infeksi, penyakit yang ditularkan melalui darah, dan vektor penyakit. Sementara itu hazard nonbiologis terdiri dari stress; kekerasan fisik, psikologis, seksual, dan kekerasan verbal; gangguan muskuloskeletal, terjatuh atau terpeleset, patah tulang; dan terpapar bahan kimia berbahaya contohnya memasang infus dan menjahit luka. Potensi bahaya pada tindakan ini adalah tertusuk jarum infus dan terpapar darah pasien yang terjadi karena ketika jarum ditusukkan ke vena, pasien bergerak dan mengenai jari perawat atau yang melakukan pembendungan pada pembuluh darah yang akan diinfus (stuwing) atau bisa juga karena setelah pemasangan, jarum tidak ditutup atau waktu menutup menggunakan dua tangan. Bahaya dari pekerjaan yang menggunakan jarum ini sangat signifikan sebagaimana penelitian yang dilakukan oleh Manzoor et al. (2010) mendapatkan Apabila tertusuk jarum yang sudah dipakai, maka berisiko tertular HIV walaupun persentasenya kecil dengan 
persentase $1 \%$. Bahaya lain yang teridentifikasi adalah bahaya sarana kerja, seperti tempat tidur yang rendah karena pengatur tinggi rendahnya tidak berfungsi sehingga perawat dalam bekerja harus membungkuk 900 yang dapat menyebabkan low back pain. Pada tindakan menjahit luka, bahaya yang teridentifikasi adalah luka kena pecahan ampul obat anestesi. Bahaya ini terjadi pada tahap menyiapkan obat anestesi, perawat memecahkan ampul obat tanpa menggunakan APD atau pelindung lain sehingga pecahan ampul obat langsung mengenai jari tangan. Tertusuk jarum jahit terjadi pada tahap penjahitan luka, hal ini terjadi karena perawat menjahit tidak menggunakan pinset untuk menahan tepi luka, tetapi menggunakan jari tangannya sendiri. Bahaya lain yang teridentifikasi adalah posisi kerja yang tidak normal sehingga perawat harus membungkuk, postur tubuh yang janggal ini karena sarana kerja yang tidak ergonomis. Hasil penelitian ini sejalan dengan penelitian Cho et al. (2013) yang menyimpulkan mayoritas perawat $(70,4 \%)$ di rumah sakit di Korea Selatan mengalami luka akibat tertusuk jarum suntik atau jarum infus. Kejadian ini berhubungan dengan faktor karekteristik perawat dan karakteristik organisasi rumah sakit. Pada tindakan pemasangan infus, risiko tertusuk jarum sering terjadi. Beberapa hal yang menjadi alasan karena memasang infus adalah tindakan yang paling sering dilakukan oleh perawat IGD dengan frekuensi 5-10 kali setiap giliran kerja sehingga frekuensi paparan antara bahaya dan sumber risiko diberi rating 10 (continuosly).

Faktor lain yang dapat menjadi titik penilaian adanya stres kerja adalah efek fisiologis yang dialami oleh perawat yang menggunakan sistem kerja shift. bahwa sistem kerja menggunakan shift memiliki efek yang tidak begitu baik bagi kesehatan seorang tenaga kerja. Dimana fungsi tubuh akan meningkat pada siang hari dan menurun pada malam hari, jika terjadi ketidaknormalan pada hal tersebut akan mengakibatkan beberapa gangguan, seperti halnya gangguan tidur, kelelahan, gangguan detak jantung, produksi adrenalin, gangguan tekanan darah hingga gangguan kemampuan fisik. 


\section{Penutup :}

Pengendalian risiko bertujuan untuk meminimalisasi efek negatif atau meningkatkan peluang positif. Hal ini dapat dilakukan pada proses kerja, peraturan atau SOP, dan melengkapi alat pelaksanaan atau tindakannya. Sesuai dengan standar internasional, pengendalian risiko di tempat kerja terdiri dari elimination, substitution, engineering control, administrative control, dan personal protective equipment (PPE). Eliminasi adalah menghilangkan potensi bahaya dari sumbernya, substitusi adalah mengganti alat, bahan atau prosedur yang berbahaya dengan yang lebih aman, engineering control adalah rekayasa teknik, adminstrative control adalah rekayasa adminstrasi, dan upaya terakhir jika semua upaya sebelumnya dirasakan belum optimal adalah memberikan alat pelindung diri (CDC, 2012; \& NYCOHS, 2012). Upaya pengendalian risiko K3 pada perawat dilakukan dengan mengikuti kaidah-kaidah hierarchy of control K3 yang disesuaikan dengan jenis tindakan keperawatan yang dilakukan. Pada tindakan pemasangan infus, risiko paparan faktor fisik dan biologis dikendalikan melalui upaya eliminasi/substitusi (seperti mengurangi tindakan injeksi yang tidak perlu, menghilangkan benda tajam/jarum yang tidak diperlukan, menggunakan konektor tanpa jarum); upaya pengandalian engineering (seperti pengaturan pencahayaan yang tepat dan ruang yang memadai, penggunaan jarum infus yang lebih aman, dan penyediaan kontainer bekas jarum infus); upaya pengendalian administratif (seperti pengembangan kebijakan K3 rumah sakit dan penyelenggaraan berbagai program pelatihan, serta penyusunan SOP pemasangan infus yang aman; dan penggunaan alat pelindung diri yang memadai (seperti penggunaan sarung tangan, masker dan gown) (Gallagher \& Sunley, 2013) Upaya pengendalian untuk risiko ergonomi dapat dilakukan dengan mengganti/ memperbaiki tempat tidur yang bisa diatur ketinggiannya agar bisa disesuaikan dengan tinggi perawat (engineering control). Pada tindakan menjahit luka, risiko paparan faktor biologi dapat dicegah dengan meningkatkan pengetahuan mengenai tindakan aman melalui pelatihan tindakan medikal bedah, sosialisasi K3, pemeriksaan secara berkala, memberikan vaksin untuk petugas yang berisiko, pengawasan terhadap pelaksanaan SOP, dan membuat SOP kejadian tidak diharapkan (KTD) agar apabila terjadi kecelakaan kerja ada pedoman yang harus dilakukan. Secara umum dapat disimpulkan bahwa 
perawat di instalasi gawat darurat berisiko untuk mengalami gangguan terhadap kesehatan dan keselamatan kerja yang bersumber dari aktivitas asuhan keperawatan yang dilakukannya, untuk itu diperlukan berbagai upaya pengendalian risiko. Langkah awal agar pengendalian berbagai risiko kesehatan dan keselamatan kerja untuk perawat di Rumah Sakit agar berhasil optimal maka perlu dibudayakan K3 di berbagai bagian di Rumah Sakit. Sesuai dengan pendapat Mulyati dkk. (2016) bahwa budaya keselamatan dan kesehatan kerja di Rumah Sakit merupakan kunci untuk tercapainya peningkatan kesehatan dan keselamatan kerja dalam organisasi. 


\section{Daftar Pustaka}

Effendy. 2013. Strategi Pengembangan Sistem Manajemen K3 pada Rumah Sakit UmumDaerah Kayuagung Kabupaten Ogan Komering Ilir. JPFEBUNSOED, (online)3(1)

Hanifa, N. D., Respati, T., \& Susanti, Y. (2017). Hubungan Pengetahuan Dengan Upaya Penerapan K3 Pada Perawat. Artikel Penelitian, 1(1),1-6

Keputusan Menteri Kesehatan Republik Indonesia Nomor 432/Menkes/SK/IV/2007 Tentang Pedoman Manajemen Kesehatan dan Keselamatan Kerja (K3) di Rumah Sakit.

Octavia, W. R., Nerawati, A. T., \& Sari, E. (2018). Penerapan Pelayanan Kesehatan Dan Keselamatan Kerja Pada Perawat IGD RUMAH SAKIT UMUM DR.WAHIDIN SUDIRO HUSODO MOJOKERTO Tahun 2017. Gema Kesehatan Indonesia, 4 (2), 1-9

Putri, O. Z., Mohammad, T., Hussin, A. B., \& Kasjono, H. S. (2017). Analisa Resiko keselamatan dan Kesehatan Kerja Pada Petugas Kesehatan Instalasi Gawat Darurat Rumah Sakit Akademika UGM. Jurnal Kesehatan, 10(1), 1-12

Ramdan, I. M., Rahma, A. (2017). Analisa Resiko Kesehatan dan Keselamatan Kerja (K3) Pada Perawat. JKD, 5(3), 229-241

Salmawati, L., Rasul, M., \& Napirah, M. (2019). Faktor yang Berhubungan dengan Kejadian Kecelakaan Kerja Pada Perawat Di Ruang IGD RSU ANUTAPURA KOTA PALU. Jurnal Kesehatan Masyarakat 10(2), 104-112

Silambi, D., Sakka, A., \& Saptaputra, S. (2019). Analisa Resiko BAhaya di Instalasi Gawat Darurat (IGD) Rumah Sakit Umum Daerah Kota Kediri Tahun 2019. Jurnal Kesehatan dan Keselamatan Kerja Universitas Halu Oleo 1(1), 1-8

Simamora, R. H. (2011). ROLE CONFLICT OF NURSE RELATIONSHIP WITH PERFORMANCE IN THE EMERGENCY UNIT OF HOSPITALS RSD DR. SOEBANDI JEMBER. The Malaysian Journal of Nursing, 3(2), 23-32. 
Yunita, A., A, Sritami, A., \& Fatmasari, E.(2016). Analisa Faktor-Faktor Kebijakan Dalam Implementasi Program Keselamatan Dan Kesehatan Kerja Rumah Sakit (K3RS) Di Instalasi Gawat Darurat Rumah Sakit Umum Daerah Kota Semarang. Jurnal Kesehatan Masyarakat, 4(2), 1-9

Yudi, D., Tangka, J., \& Wowling, F. (2019). Hubungan Beban Kerja Fisik dan Mental Perawat Dengan Penerapan Patient Safety Di IGD Dan ICU RSU GMIM Pancaran Kasih Manado. Jurnal Keperawatan, 7(1), 1-9

Yulistuti, F. (2014). Komparasi Tingkat Stress Kerja Ditinjau Dari Sistem Kerja Pada Perawat Instalasi Gawat Darurat (IGD) Di Kota Magelang. Naskah Publikasi, 1-19 